\title{
Concluding Remarks by Sean D. Murphy
}

My thanks to the organizers of this conference in celebration of the Commission's seventieth anniversary. The topic of this panel is an important one, as it goes to the heart of what the Commission has done in the past and will do in the future. Indeed, when I first joined the Commission in 2012, I often found myself asking, when a particular rule was under discussion, "are we trying to codify the law or progressively develop it?" I believed the answer to that question to be extremely important, as otherwise it was unclear on what terrain a discussion was taking place. There seemed little point in trying to persuade colleagues why a particular rule was not grounded in existing law if, in their view, that position was irrelevant to the task at hand.

Through their papers, Yifeng Chen and Ineta Ziemele have provided important insights into the Commission's mandate with respect to the progressive development and codification of international law, and its implementation of that mandate from its inception to the present. Yifeng Chen quite rightly reminds us of the aspirations for codification over the past century, the philosophy underlying the codification movement, and the distinction between codification and progressive development, all as a backdrop to asking important questions about the authority and legitimacy of the Commission.

Ineta Ziemele argues that the international law landscape has changed since the inception of the Commission, raising serious questions about what should be the function of the Commission as it pursues its twin mandates. The real impact of the Commission is brought alive in her discussion of the engagement of the European Court of Human Rights with the work of the Commission, but that impact arguably can only be maintained if the Commission pursues a more activist approach to our "globalized world", bringing into its thinking the views of disparate actors beyond just States.

In my brief role as discussant of those papers, I would like to address some of the themes advanced within them principally by considering, from an "insider's perspective", two questions: (1) what factors push the balance within the Commission either in the direction of "codification" of international law or in the direction of "progressive development?"; and (2) what factors push the balance with respect to any given draft article (or other provision) in the direction of transparency by the Commission as to what it thinks it is doing (codification 
or progressive development) or in the direction of obscuring what it thinks it is doing?

In considering the answers to those questions, it is important to understand two points. First, the original scheme envisaged in the Commission's statute drew a relatively bright line between the process of codification and the process of progressive development, which was never operationalized. ${ }^{1}$ Rather, from the start, the Commission recognized that its projects inevitably contained elements of both codification and progressive development.

Second, precise definitions of "codification" and of "progressive development" of the law are allusive. The Commission's statute defines the two terms in a certain way, ${ }^{2}$ but those definitions typically are not what most persons mean when they use the terms. In fact, and ironically, the contemporary understanding seems to be the opposite of what is said in the statute, in that many today regard the "draft articles" prepared by the Commission (ostensibly as possible articles for a treaty) as codifying international law, when the statute indicates that the preparation of draft conventions is done to progressively develop the law. Even so, I think the contemporary understanding of these two terms is relatively widespread, and centers on the idea of "codification" as an exercise in systematizing existing rules of international law, and on progressive development as an exercise in: (1) identifying a rule for which there is some but not widespread support in State practice; (2) filling gaps in the existing law; or, perhaps, (3) proposing entirely new law. ${ }^{3}$

1 See, for instance, Donald McRae, "The Work of the International Law Commission, 20072011: Progress and Prospects' (2012) 106 AJIL 322, 324 ("the widely held view is that the Commission has never actually followed that distinction in practice"); Michael Wood, "The United Nations International Law Commission and Customary International Law' (Gaetano Morelli Lecture 4th edn: Rethinking The Doctrine Of Customary International Law, Rome, 27 May 2017) para 27. <https://www.scienzegiuridiche.uniroman.it/sites/default/files/varie/GML/ 2017/GML_2017-Wood.pdf > ("it has long been accepted that the Commission does not and cannot follow the distinction made in its statute, at least as far as working methods are concerned").

2 Article 15 of the ILC statute provides: "In the following articles the expression "progressive development of international law" is used for convenience as meaning the preparation of draft conventions on subjects which have not yet been regulated by international law or in regard to which the law has not yet been sufficiently developed in the practice of States. Similarly, the expression "codification of international law" is used for convenience as meaning the more precise formulation and systematization of rules of international law in fields where there already has been extensive State practice, precedent and doctrine."

3 For a thoughtful discussion, see Donald McRae, "The Interrelationship of Codification and Progressive Development in the Work of the International Law Commission' (2013) 111 JILD 75 . 


\section{Factors Influencing Codification versus Progressive Development}

With that in mind, I turn to the first question: what factors push the balance within the Commission either in the direction of "codification" of international law or in the direction of "progressive development"? In my view, much of what the Commission does is progressive development of the law, even if it is commonly perceived by others as codification. ${ }^{4}$

One major factor pushing the Commission in the direction of codification is the desire for the rules contained in its work to be generally accepted by States and others, which is maximized if the work is based not on the preferences of the members of the Commission, but on a rigorous and systematic analysis of existing State practice and international jurisprudence.

A related factor is the desire by the Commission to have influence on the field of international law even if its work is not transformed into a treaty. The fact that the Commission's work in recent years has rarely resulted in a treaty instrument, ${ }^{5}$ and that the Commission instead has moved toward other forms of "packaging" its work, ${ }^{6}$ is well understood. Indeed, of the nine topics on the Commission's agenda in July 2018, only three are cast as "draft articles"7 and, of those three, I would venture to say that only one is viewed as actually having the potential for transformation into a treaty. ${ }^{8}$ The remaining topics cast as

4 McRae (n 1 ) 324 ("much of what the Commission does is progressive development, although not necessarily seen or characterized as such”); see also David Caron, 'The International Law Commission Articles on State Responsibility: The Paradoxical Relationship Between Form and Authority' (2002) 96 AJIL 857, 861 ("the fact that the International Law Commission study is written as though it were a treaty in many instances will not result in its being a document that changes and grows with the testing of particular cases, but one that is inappropriately and essentially accorded the authority of a formal source of law.").

5 See Michael Wood, "The General Assembly and the International Law Commission: What Happens to the Commission's Work and Why?' in Isabelle Buffard et al (eds), International Law between Universalism and Fragmentation, Festschrift in Honour of Gerhard Hafner (Brill 2008) 373 .

6 See Sean D Murphy, 'Codification, Progressive Development, or Scholarly Analysis? The Art of Packaging the International Law Commission's Work Product' in Maurizio Ragazzi (ed), The Responsibility of International Organizations: Essays in Memory of Sir Ian Brownlie (Martinus Nijhoff 2013) 29.

7 The topics of "Crimes against humanity," "Immunity of State officials from foreign criminal jurisdiction," and "Succession of States in respect of State responsibility".

8 The topic of "Crimes against humanity". See also ILC, "Report of the International Law Commission on the work of its sixty-eighth session' (2016) UN Doc A/68/10, 140 at para 3 . 
"draft conclusions,"9 "draft guide,"10 "draft guidelines,"11 or "draft principles,"12 will not become treaty instruments. The closer the work adheres to codification, the more influence it will likely have, for it is validated by existing State practice and international jurisprudence (rather than through subsequent adoption and ratification by States).

A third factor is a recognition by many if not most members of the Commission that it was not established as a law-maker or legislator. ${ }^{13}$ Rather, its mandate of "progressive development" was originally designed as a part of a process of treaty-making by States. Assuming a role of law-maker by advancing new rules in instruments that are not expected to become treaties is perilous, potentially threatening over the long-term the legitimacy of the Commission.

On the other side of the ledger, one factor pushing the Commission toward progressive development of the law is a desire to build a better world. Codification is sometimes seen as accepting and even "freezing" in place lacunae, faults, inadequacies, or inequities in existing law, whereas progressive development presents an opportunity to improve upon the law, to push States to do better. For some, the value of the Commission is not to just look backwards, but to look forward, extrapolating from where we are to where we might and should be.

A second factor pushing the Commission toward progressive development of the law is, quite frankly, that true codification is an extremely difficult and time-consuming task. To properly codify a rule, one must try to account for the practice of 193 different States, consider those practices in conjunction with opinio juris, and then analyze if such practice and acceptance of the practice is sufficiently widespread and representative. It becomes quite a daunting task, even when there are multilateral treaties, or resolutions of international organizations or intergovernmental conferences, that may assist in the analysis.

A third factor is that even assuming perfect knowledge with respect to the practice of States (and, if deemed relevant, thousands of international organizations), there will inevitably be some gaps in that practice, often making it difficult to say that a rule is definitively settled. As such, there is an impetus to

The topics of "Identification of customary international law," "Subsequent agreements and subsequent practice in the interpretation of treaties," and "peremptory norms of general international law (jus cogens)".

10 The topic "Provisional application of treaties".

11 The topic "Protection of the atmosphere".

12 The topic "Protection of the environment in relation to armed conflict".

13 Wood (n 1) at para 11 ("neither the General Assembly, nor its subsidiary organ, the Commission, has the power to make law"). 
see the practice as "good enough" for at least progressive development of the law, even if not for codification.

\section{Factors Influencing Transparency about What the Commission is Doing}

Turning to the second question: what factors push the balance in the direction of transparency by the Commission as to what it is doing (codification or progressive development) or in the direction of obscuring what it thinks it is doing? Such disclosure normally would occur through what is said in the Commission's commentary, either at the outset in a "general commentary" of a project ${ }^{14}$ or along the way in its commentary with respect to individual draft articles or other provisions. As it happens, the Commission typically does not disclose, as least expressly, whether it is engaged in codification or progressive development. ${ }^{15}$

One factor that pushes the Commission toward disclosure as to whether an entire project or a given provision is codifying or progressively developing international law is that helps it address the legitimacy concern noted above. If the Commission is convinced that it is codifying international law, it can say as much and then back up the claim with its evidence. If the Commission knows that a particular provision is progressively developing the law, and

14 A good example of this would be the inclusion in the Commission's general commentary to the articles on the responsibility of international organizations of a statement that the fact that several of the draft articles are based on limited practice 'moves the border between codification and progressive development in the direction of the latter [...] In other words, the provisions of the present draft articles do not necessarily yet have the same authority as the corresponding provisions on State responsibility'. ILC, 'Report of the International Law Commission on the work of its sixty-third session' [2011] II(2) ILC Ybk 40, 46.

15 By way of example, the beginning of the Commission's general commentary to the draft articles on responsibility of States for internationally wrongful acts essentially reiterates the mandate of the Commission when noting: "These articles seek to formulate, by way of codification and progressive development, the basic rules of international law concerning the responsibility of States for their internationally wrongful acts." Draft articles on responsibility of States for internationally wrongful acts, in ILC, 'Report of the International Law Commission on the work of its fifty-third session' [2001] II(2) ILC Ybk 26, 141 ("The present articles set out by way of codification and progressive development the general secondary rules of State responsibility"). At the same time, the commentary thereafter expressly identifies two situations where a rule constitutes progressive development of the law, ibid at 127, 114, which might imply that the Commission regards the other rules as codification. 
further knows that its work will not be adopted as a treaty, then disclosing that the provision is progressive development helps insulate the Commission from charges that it is assuming the mantle of legislator. Instead, the Commission is offering a rule that it thinks appropriate, but is candidly acknowledging that the rule is a product of the Commission's own views, rather than a synthesis of settled law.

Another factor that pushes the Commission towards transparency is an understanding that relevant actors who may be relying on the Commission's work, in certain circumstances, need clarity as to what is lex lata and what is lex desiderata. A court for example, and especially a criminal court, typically must know the law as it is, not as it might be. Transparency by the Commission helps the court to understand, in any given instance, which of the Commission's twin mandates is in play.

A final factor is that, in some instances, such transparency can help members to reach consensus on the adoption of a provision. Some members may be resisting a proposed rule due to a belief that the rule is not well-settled. Identifying the rule as a form of progressive development is a means of addressing such a concern, allowing agreement to be reached on the rule by means of its characterization in the commentary.

Yet there are also factors that push the Commission away from transparency. Indeed, the dominant posture of the Commission is not to be transparent about what it is doing, at least in the sense of expressly identifying in the commentary whether a particular provision is codification or progressive development of the law. One factor pushing in the direction of non-disclosure picks up where the prior paragraph left off, which is to say that members often do not agree whether a particular provision is codification or progressive development. The easiest course to take, then, is for the Commission to say nothing at all, leaving members individually to characterize the rule as they wish.

A second factor is a sense among some members of the Commission that transparency already exists. Relevant actors already know that the Commission's mandate spans both codification and progressive development, so they are on notice at a general level as to what the Commission is doing. It is possible that the packaging of the project provides certain signaling; the title "conclusions" may signal codification, whereas "guidelines" or "principles" signal softer, more progressive thinking (since the Commission has nowhere indicated what these titles mean, however, it is hard to know exactly their significance). If a more granular understanding is needed for any given provision, then a close reading of the commentary helps guide the reader. Where the Commission has cited to copious State practice and jurisprudence backing up 
the asserted rule, then codification can be assumed; if not, then progressive development. ${ }^{16}$

A third factor is the desire not to "freeze" the law. Even if all members view a particular provision as progressive development, saying as much might inhibit the crystallization of the rule as law, since the Commission is on record doubting that it is yet well-settled. As the late David Caron noted, "the freezing effect of a code may be greater because the system lacks both a legislative body to amend the codes and an authoritative judiciary with jurisdiction over enough cases to adapt them to new circumstances and needs." ${ }^{17}$

Finally, no doubt some members view the concern with diminishment of the "legitimacy" of the Commission as misguided, given the Commission's relationship with States through the Sixth Committee of the United Nations General Assembly. ${ }^{18}$ Even if the Commission's work is not transformed into a treaty, it is reviewed, debated, and sometimes expressly accepted or rejected by States through oral comments made in the Sixth Committee debate each fall, and through written comments submitted send to the United Nations. If the Commission goes out on a limb of progressive development that States do or do not like, they can react accordingly. Reading the Commission's work in conjunction with the reaction of States provides for assessing and even generating law, through State practice prompted by the Commission's work. On this account, there is no need for greater transparency by the Commission as to what it is doing, for the key ingredient is not what the Commission says but what States say about what the Commission says. A weakness, of course, in this line of argument is that the reaction of States to the Commission's work is serious and substantial, but far from thorough. At most, 40 to 50 States participate in the debate in the Sixth Committee, with interventions that are often vague, circumspect or ambiguous, and even fewer States submit written comments.

In conclusion, the perplexing phenomenon of codification versus progressive development is an enduring characteristic of the work of the International Law Commission, one that will no doubt be at issue in anniversary celebrations to come.

16 See McRae (n 1 ) 330 ("When no practice is available on which [to] base a draft article, the case for saying that it represents an existing principle of customary international law is weak.").

17 Caron (n 4) 861.

18 For discussion of that relationship, see Franklin D Berman, 'The International Law Commission within the United Nation's Legal Framework: Its Relationship with the Sixth Committee' [2006] 49 GYIL 107; see also Pemmaraju Sreenivasa Rao, 'International Law Commission' in Rüdiger Wolfrum (ed), Max Planck Encyclopedia of Public International Law (OUP 2O12), para 14. 
The United Nations - 9789004434271

Downloaded from Brill.com04/26/2023 02:14:34PM via free access 